Nigerian Journal of Environmental Sciences and Technology (NIJEST)

www.nijest.com

ISSN (Print): 2734-259X｜ＩSSN (electronic): 2734-2603

Vol 5, No. 1 March 2021, pp 1 - 12

\title{
Multilinear Regression Model to Estimate Mud Weight
}

\author{
Oloro J. O. ${ }^{1}{ }^{*}$ and Akhihiero T. E. ${ }^{2}$ \\ ${ }^{1}$ Department of Chemical and Petroleum Engineering, Faculty of Engineering, Delta State University, Delta \\ State, Nigeria \\ ${ }^{2,3}$ Department of Chemical Engineering, Faculty of Engineering, University of Benin, Benin City, Edo State, \\ Nigeria \\ Corresponding Author: *olorojo@delsu.edu.ng
}

https://doi. org/10.36263/ni jest. 2021.01.0229

\begin{abstract}
Estimation of mud weight poses a serious challenge to mud industries. In this study, a model was developed to tackle the problem of estimation of mud weight using multilinear regression techniques. The model was developed using data obtained from production records. The data include mud weight, water and other chemicals (materials) for nine different samples. The data were analysed to establish linearity and the data was substituted into the multiple regression to form a matrix with nine unknown regression parameters which was substituted into the regression equation to form the model. $T$-test and $F$-test was used to validate the model. Results from the test suggest that the developed model was reliable. The model was used to estimate mud weight for four samples and the results are reliable. The effect of each variable was also considered and results also show that each of the variables affects the mud weight.
\end{abstract}

Keywords: Regression, Fluid, Mud weight, Caustic soda, Barite

\subsection{Introduction}

Mud is usually prepared to meet certain properties which enable it to perform the basic intended functions. Mud is an element that characterized the quality of the drilling. The researches and survey conducted; there are likelihoods of having environmentally friendly mud. The operators of gas and oil industries are faced with the challenge of getting a solution to this problem by formulating highquality mud and also negative environmental conventional diesel oil base mud effects. The more environmentally welcoming acceptable alternative to oil-base mud (OBM) found is water base mud (Sir Dele and Joseph, 2014).

Drilling mud varies in degrees of toxicity. It is very costly and tedious to dispose of it in an environmentally friendly way. Protection of the environment from pollutants is important in every drilling operation. Mud Companies have restrictions placed on some materials they use and the methods of their disposal. At the beginning of the 1990s, the restrictions are becoming more stringent and restraints are becoming worldwide issues (Enamul et al., 2016).

Regular interval testing of mud properties will help Mud Engineers to determine the proper functioning of mud (Fadairo et al., 2012). Mud is classified into:

1. Pneumatic fluids: Pneumatic fluids are used for drilling low fluid zones or an area where unusual little formation pressures may be experienced. Pneumatic fluids are better than other liquid mud systems since it increases penetration rates. Air/gas mud fluids are not effective in an area where large volumes of formation fluids are experienced. Hence, the chances of losing circulation or damaging a productive zone are greatly increased. One other factor when considering the selection of pneumatic fluids is the well depth. They are not approved for wells below $10,000 \mathrm{ft}$ since the volume of air essential to lift cuttings from the bottom of the hole can become larger than the surface apparatus can deliver. 
2. Oil-based mud: The main use of oil-based fluids is to drill difficult shale. They are also used in the drilling of exceedingly deviated holes because of their high performance of its lubricity and tendency to stop hydration of clays. They may also be chosen for distinct applications such as high pressure /high-temperature wells, lessening formation damage, and native-state coring. Another reason for selecting oil-based fluids is that they are resilient to contaminants such as anhydrite, salt, and $\mathrm{CO}_{2}$ and $\mathrm{H}_{2} \mathrm{~S}$ acid gases.

3. Water-based mud; Water-based fluids are the most widely used drilling fluids. They are normally easy to build, inexpensive to maintain, and can be prepared to overcome most drilling problems.

Testing of mud is not limited to the kind of drilling mud for each hole interval but also to properties of such mud; density, rheology (flow properties), filtration and solid content and also chemical properties. Mud properties are field controlled and properly maintained at their preselected values; to avoid drilling problems. But this work is restricted to mud weight (density). Mud density is the weight per unit volume. The unit is given as pounds per gallon (lb/gal). Mud weight is a significant parameter which is controlled during a drilling operation. To avoid formation fluids to flow into the wellbore and to seal the wellbore with a low permeability filter cake, the weight of the mud must be greater than the pore pressure of the formation. However, the mud weight column should not be high enough to cause formation fracture. The weighting agents used in mud building are barite, hematite, galena, calcium carbonate. Statistically, barite is the most wildly used weighing agent. All materials present in mud contribute to its weight (Sharif et al., 2017). The resulting mud mixture from all the additives and water is assumed to be ideal. Hence, the total volume is the addition of the component volumes and the total weight (density) is equal to the sum of the component weight add depending on the function (Øyvind, 2017).

Mud weight is employed to subsurface pressure and stabilizes the wellbore; mud weight is commonly measured with a mud balance capable of $+0.1 \mathrm{lb} / \mathrm{gal}$ accuracy. A mud balance calibrated with the freshwater of $70 \mathrm{o} \pm 5 \mathrm{o}$ should give a reading of $8.3 \mathrm{lb} / \mathrm{gal}$. Mud weight is usually reported in $\mathrm{g} / \mathrm{ml}$ or $\mathrm{lb} / \mathrm{gal}, \mathrm{lb} / \mathrm{cuft}$, or psi/100ft of depth.

Mud balance is an instrument used in the laboratory to calculate mud weight. This instrument was manufactured by Fann. The name of the mud balance is Model 140. It has a range of 7 to $24 \mathrm{lb} / \mathrm{gal}$. The measurement taken was reported to the nearest $0.1 \mathrm{lb} / \mathrm{gal}$.

Estimation of mud weight poses is a serious challenge in the mud industry. Therefore in this study, a model was developed to tackle the problem of estimation of mud weight using multilinear regression techniques. The model was developed using data obtained from the production record. The data include the quantity of mud produced and mud utilize for nine different samples (Sample 1 - Sample 9). The data was analysed to establish linearity and the data was substituted into the multiple regression to form a matrix with nine unknown regression parameters which was substituted into the regression equation to form the model.

\subsection{Methodology}

\subsection{Materials}

Materials and method investigation involved a series of laboratory works which was initiated with the preparation of water base mud as the continuous phase system. The mud sample is prepared as per field formulations, which comprised of freshwater, potassium chloride, caustic soda, soda ash, PAC $\mathrm{R}$, PAC L, XCD. The weighting materials were then added into the mud separately to form the required mud weight, ranging from 9ppg to 14ppg. Different ppg was gotten as a result of using different quantities of materials (chemicals). Multiple regression was developed using the least square method. The different mud weights gotten are plotted against each material (chemical) to determine the linearity of the regression (Burgoyne et al., 1986; John et al., 2018; Bill and Nicole, 2018). The regression parameters obtained using excel program were plugged into the regression model to obtain the required equation. Thereafter the model was tested for validity using t-test and F-test (Andy, 2000) The materials and equipment used for work are summarized in Table 1 . The mud weight of the mud samples was determined by using the conventional mud balance, whilst the retort apparatus was used 
to find the solid content of the mud sample. All the laboratory works were conducted according to the API standard procedures (API, 2003; Paulauskiene, 2017).

Table 1: Equipment and materials (chemical)

\begin{tabular}{|l|l|}
\hline Materials & Equipment \\
\hline Water & Mud balance \\
\hline Barite & Retort kit \\
\hline Carboxymethyl cellulose (CMC) & Halminton Beach Mixer \\
\hline Potassium chloride (KCl) & Electrical weighing balance \\
\hline Polyanionic Cellulose (Pac-R) & Round bottom flask \\
\hline Caustic Soda & Rotary viscometer \\
\hline Soda Ash & API filter press \\
\hline XCD Kelzan & pH meter \\
\hline Calcium Carbonate & \\
\hline
\end{tabular}

\subsection{Relationship between variables}

Often in practice, a relationship is found to exist between two or more variables. For example; weights of mud depend on calcium carbonate; soda ash; Potassium chloride $(\mathrm{KCl})$; polyanionic cellulose (Pac-R); barite; carboxymethyl cellulose (CMC) and caustic Soda. Figure 1 to Figure 9 is plotted to determine the mathematical relationship between mud weight and other variables.

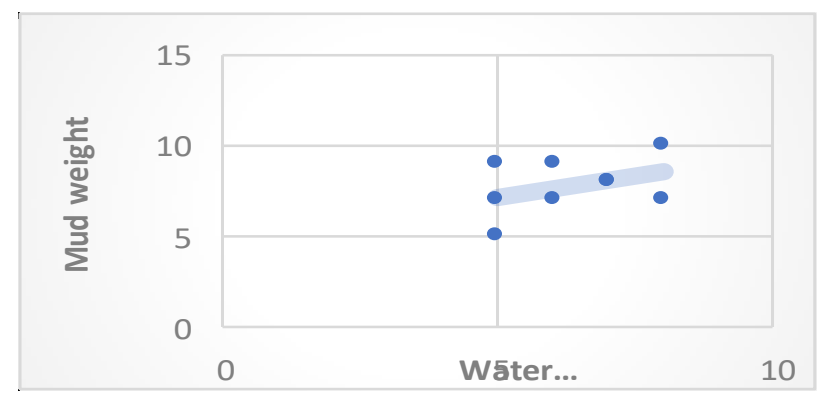

Figure 1: Quantity of water $\left(\mathrm{X}_{1}\right)$ used to produce total mud weight

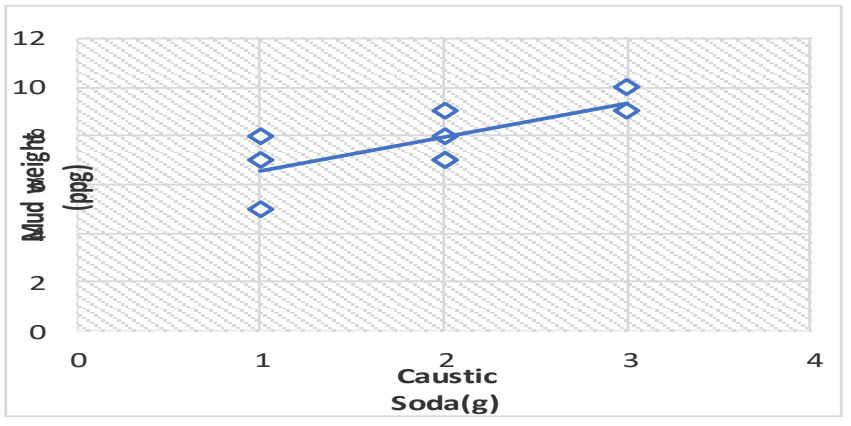

Figure 2: Quantity of caustic soda $\left(\mathrm{X}_{2}\right)$ used to produce total mud weight

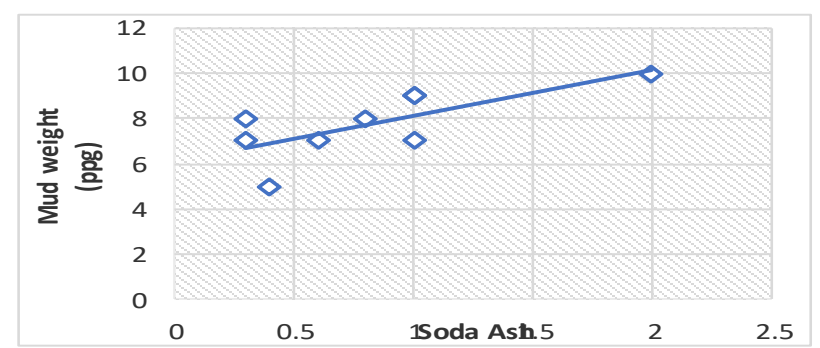

Figure 3: Quantity of soda ash $\left(\mathrm{X}_{3}\right)$ used to produce total mud weight 


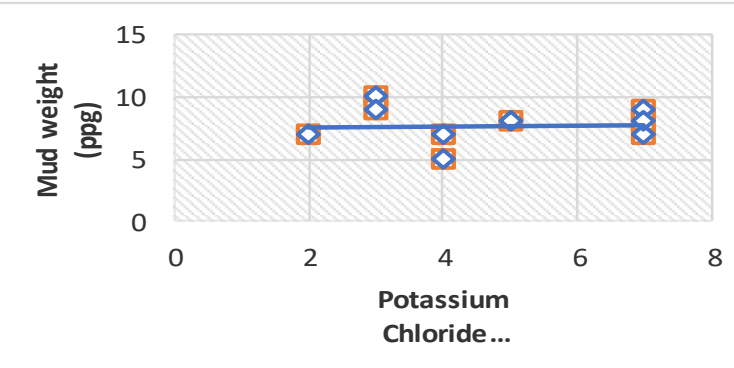

Figure 4: Quantity of potassium chloride $\left(\mathrm{X}_{4}\right)$ used to produce total mud weight

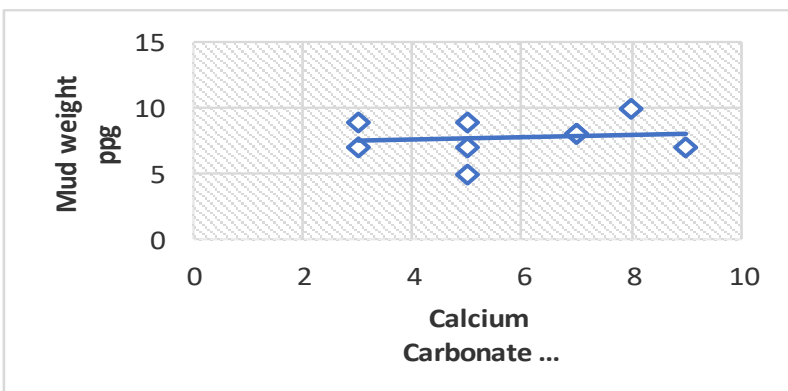

Figure 5: Quantity of calcium carbonate, $\mathrm{CaCO}_{3}\left(\mathrm{X}_{5}\right)$ used to produce total mud weight

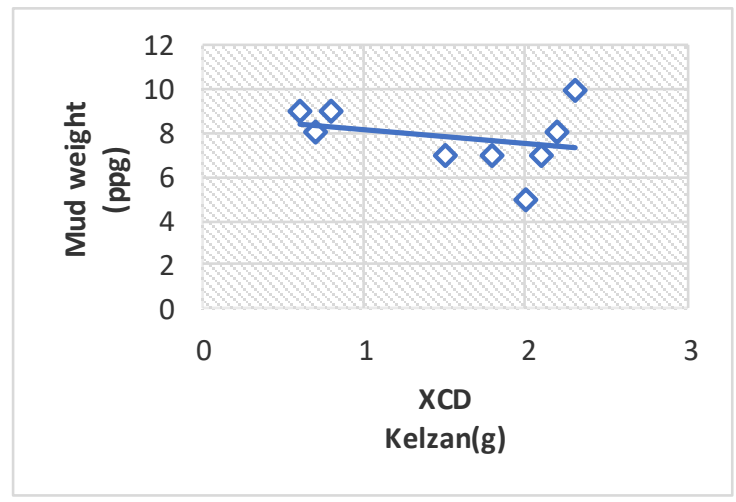

Figure 6: Quantity of XCD Kelzan $\left(\mathrm{X}_{6}\right)$ used to produce total mud weight

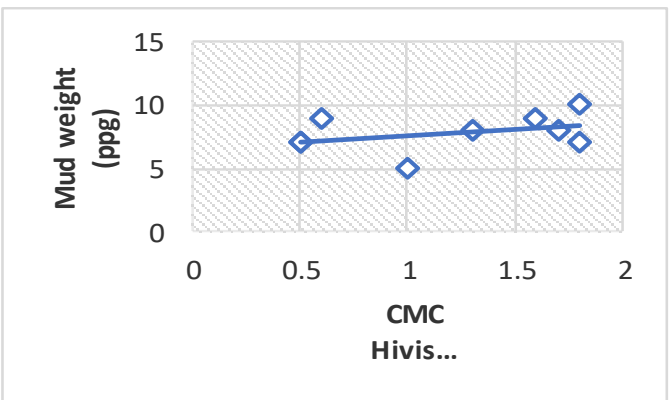

Figure 7: Quantity of PAC-R $\left(\mathrm{X}_{7}\right)$ used to produce total mud weight 


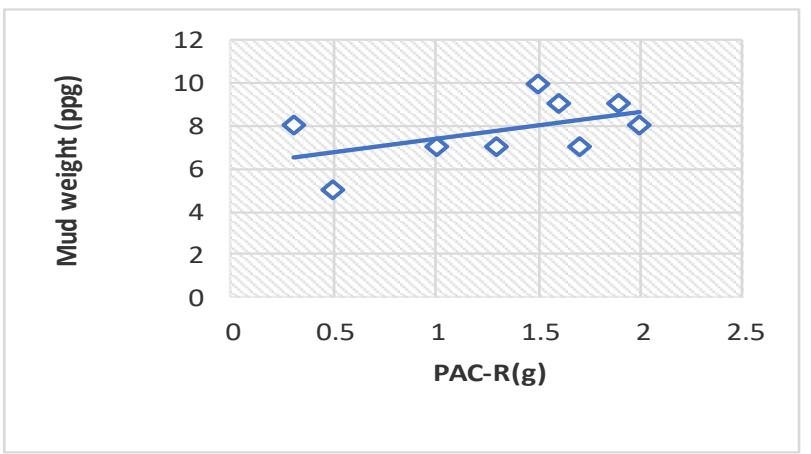

Figure 8: Quantity of PAC-R $\left(\mathrm{X}_{8}\right)$ used to produce total mud weight

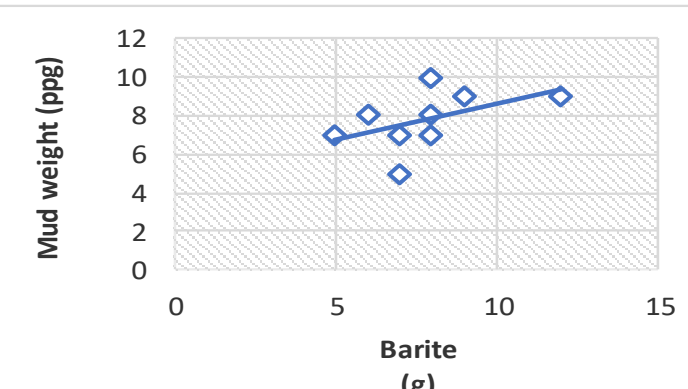

(g)

Figure 9: Quantity of barite $\left(\mathrm{X}_{9}\right)$ used to produce total mud weight

Table 2: Data to prepare mud weight

\begin{tabular}{|c|c|c|c|c|c|c|c|c|c|c|}
\hline S/N & $\begin{array}{l}\text { Mud } \\
\text { weight } \\
(\mathrm{ppg})\end{array}$ & $\begin{array}{c}\text { Water } \\
\mathrm{X}_{1}(\mathrm{litr})\end{array}$ & $\begin{array}{c}\text { Caustic } \\
\text { soda(g) } \\
\mathrm{X}_{2}\end{array}$ & $\begin{array}{c}\text { Soda } \\
\mathrm{ash} \\
\mathrm{X}_{3}\end{array}$ & $\begin{array}{c}\text { Potassium } \\
\text { chloride } \\
(\mathrm{KCl})(\mathrm{g}) \\
\mathrm{X}_{4}\end{array}$ & $\begin{array}{c}\text { Calcium } \\
\text { carbonate } \\
\left(\mathrm{CaCO}_{3}\right) \\
\mathrm{X}_{5}(\mathrm{~g})\end{array}$ & $\begin{array}{c}\mathrm{XCD} \\
\text { Kelzan }(\mathrm{g}) \\
\mathrm{X}_{6}\end{array}$ & $\begin{array}{c}\text { CMC } \\
\text { Hivis } \\
(\mathrm{g})\end{array}$ & $\begin{array}{c}\text { PAC-R(g) } \\
\mathrm{X}_{8}\end{array}$ & $\begin{array}{c}\text { Barite } \\
(\mathrm{g}) \\
\mathrm{X}_{9}\end{array}$ \\
\hline 1 & 10 & 8 & 3 & 2 & 3 & 8 & 2.3 & 1.8 & 1.5 & 8 \\
\hline 2 & 7 & 5 & 2 & 1 & 2 & 9 & 1.8 & 1.8 & 1.3 & 8 \\
\hline 3 & 5 & 5 & 1 & 0.4 & 4 & 5 & 2 & 1 & 0.5 & 7 \\
\hline 4 & 7 & 6 & 2 & 0.3 & 7 & 3 & 1.5 & 0.5 & 1 & 7 \\
\hline 5 & 8 & 7 & 1 & 0.3 & 5 & 7 & 2.2 & 1.7 & 2 & 8 \\
\hline 6 & 9 & 6 & 3 & 1 & 3 & 5 & 0.6 & 0.6 & 1.6 & 9 \\
\hline 7 & 9 & 5 & 2 & 1 & 7 & 3 & 0.8 & 1.6 & 1.9 & 12 \\
\hline 8 & 7 & 8 & 1 & 0.6 & 4 & 5 & 2.1 & 0.5 & 1.7 & 5 \\
\hline 9 & 8 & 7 & 2 & 0.8 & 7 & 7 & 0.7 & 1.3 & 0.3 & 6 \\
\hline
\end{tabular}

\subsection{Methods}

In this paper, $Y$ is the dependent variable, while the independent variables are $X_{1}, X_{2} \ldots \ldots \ldots \ldots . ., X_{9}$ (Andy, 2000) The regression equation was formed using the parameters in Table 2 as given in Equation 1 below:

The normal equations to Equation (1) are Equation (2) through to Equation (10).

$$
Y=n b_{0}+b_{1} X_{1}+b_{2} X_{2}+b_{3} X_{3}+b_{4} X_{4}+b_{5} X_{5}+b_{6} X_{6}+b_{7} X_{7}+b_{8} X_{8}+b_{9} X_{9}
$$

where:

$\begin{array}{ll}Y & \text { mud weight } \\ X_{1} & \text { volume of water } \\ X_{2} & \text { caustic soda } \\ X_{3} & \text { soda ash } \\ X_{4} & \text { potassium chloride }(\mathrm{KCl})\end{array}$


$X_{5} \quad$ calcium carbonate $\left(\mathrm{CaCO}_{3}\right)$

$X_{6} \quad$ XCD Kelzan

$X_{7} \quad$ CMC Hivis

$X_{8} \quad$ PAC-R

$X_{9} \quad$ Barite

$$
\begin{aligned}
& \sum Y X_{1}=b_{0} \sum X_{1}+b_{1} \sum X_{1}{ }^{2}+b_{2} \sum X_{1} X_{2}+b_{3} \sum X_{1} X_{3}+b_{4} \sum X_{1} X_{4}+b_{5} \sum X_{1} X_{5} \\
& +b_{6} \sum X_{1} X_{6}+b_{7} \sum X_{1} X_{7}+b_{8} \sum X_{1} X_{8}+b_{9} \sum X_{1} X_{9} \\
& \sum Y X_{2}=b_{0} \sum X_{2}+b_{1} \sum X_{1} X_{2}+b_{2} \sum X_{2}{ }^{2}+b_{3} \sum X_{2} X_{3}+b_{4} \sum X_{2} X_{4}+b_{5} \sum X_{2} X_{5} \\
& +b_{6} \sum X_{2} X_{6}+b_{7} \sum X_{2} X_{7}+b_{8} \sum X_{2} X_{8}+b_{9} \sum X_{2} X_{9} \\
& \sum Y X_{3}=b_{0} \sum X_{3}+b_{1} \sum X_{1} X_{3}+b_{2} \sum X_{2} X_{3}+b_{3} \sum X_{3}{ }^{2}+b_{4} \sum X_{3} X_{4}+b_{5} \sum X_{3} X_{5} \\
& +b_{6} \sum X_{3} X_{6}+b_{7} \sum X_{3} X_{7}+b_{8} \sum X_{3} X_{8}+b_{9} \sum X_{3} X_{9} \\
& \sum Y X_{4}=b_{0} \sum X_{4}+b_{1} \sum X_{1} X_{4}+b_{2} \sum X_{2} X_{4}+b_{3} \sum X_{3} X_{4}+b_{4} \sum X_{4}{ }^{2}+b_{5} \sum X_{4} X_{5} \\
& +b_{6} \sum X_{4} X_{6}+b_{7} \sum X_{4} X_{7}+b_{8} \sum X_{4} X_{8}+b_{9} \sum X_{4} X_{9} \\
& \sum Y X_{5}=b_{0} \sum X_{5}+b_{1} \sum X_{1} X_{5}+b_{2} \sum X_{2} X_{5}+b_{3} \sum X_{3} X_{5}+b_{4} \sum X_{4} X_{5}+b_{5} \sum X_{5}{ }^{2} \\
& +b_{6} \sum X_{5} X_{6}+b_{7} \sum X_{5} X_{7}+b_{8} \sum X_{5} X_{8}+b_{9} \sum X_{5} X_{9} \\
& \sum Y X_{6}=b_{0} \sum X_{6}+b_{1} \sum X_{1} X_{6}+b_{2} \sum X_{2} X_{6}+b_{3} \sum X_{3} X_{6}+b_{4} \sum X_{4} X_{6}+b_{5} \sum X_{5} X_{6} \\
& +b_{6} \sum X_{6}^{2}+b_{7} \sum X_{6} X_{7}+b_{8} \sum X_{6} X_{8}+b_{9} \sum X_{6} X_{9} \\
& \sum Y X_{7}=b_{0} \sum X_{7}+b_{1} \sum X_{1} X_{7}+b_{2} \sum X_{2} X_{7}+b_{3} \sum X_{3} X_{7}+b_{4} \sum X_{4} X_{7}+b_{5} \sum X_{5} X_{7} \\
& +b_{6} \sum X_{6} X_{7}+b_{7} \sum X_{7}^{2}+b_{8} \sum X_{7} X_{8}+b_{9} \sum X_{7} X_{9} \\
& \sum Y X_{8}=b_{0} \sum X_{8}+b_{1} \sum X_{1} X_{8}+b_{2} \sum X_{2} X_{8}+b_{3} \sum X_{3} X_{8}+b_{4} \sum X_{4} X_{8}+b_{5} \sum X_{5} X_{8} \\
& +b_{6} \sum X_{6} X_{8}+b_{7} \sum X_{7} X_{8}+b_{8} \sum X_{8}^{2}+b_{9} \sum X_{8} X_{9} \\
& \sum Y X_{9}=b_{0} \sum X_{9}+b_{1} \sum X_{1} X_{9}+b_{2} \sum X_{2} X_{9}+b_{3} \sum X_{3} X_{9}+b_{4} \sum X_{4} X_{9}+b_{5} \sum X_{5} X_{9} \\
& +b_{6} \sum X_{6} X_{9}+b_{7} \sum X_{7} X_{9}+b_{8} \sum X_{8} X_{9}+b_{9} \sum X_{9}{ }^{2}
\end{aligned}
$$

\section{. 2.3. Creation of matrix}

In creating a matrix, the values of each material in Table 2 were substituted into Equations 2 to 10 to form the matrix notation. This can be written as $A \times R=C$. These unknown parameters $R$ (i.e. $b_{o}, b_{1}$, $b_{2}, b_{3}, b_{4}, b_{5}, b_{6}, b_{7}, b_{8}, b_{9}$ ) was determined using an Excel program. The results are shown below.

$\left[\begin{array}{cccccccccc}9 & 57 & 17 & 7.4 & 42 & 52 & 14 & 10.8 & 11.53 & 70 \\ 57 & 373 & 108 & 48.3 & 265 & 335 & 91.1 & 68 & 75.8 & 433 \\ 17 & 108 & 37 & 16.5 & 77 & 100 & 24.6 & 20.8 & 22.5 & 137 \\ 7.4 & 48.3 & 16.5 & 8.34 & 77 & 46.6 & 11.53 & 10 & 10.16 & 60.1 \\ 42 & 265 & 77 & 31.3 & 226 & 223 & 60.7 & 49.1 & 53.1 & 330 \\ 52 & 335 & 91.1 & 100 & 46.6 & 223 & 336 & 85.3 & 65.4 & 67.5 \\ 14 & 91.1 & 24.6 & 11.53 & 60.7 & 85.3 & 25.52 & 17.47 & 18.95 & 104.6 \\ 10.8 & 68 & 20.8 & 10 & 49.1 & 65.4 & 17.47 & 15.48 & 14.68 & 87.8 \\ 11.8 & 75.8 & 22.5 & 10.16 & 53.1 & 67.5 & 18.95 & 14.68 & 18.34 & 96.4 \\ 70 & 433 & 137 & 60.1 & 330 & 396 & 104.6 & 87.8 & 96.4 & 576\end{array}\right]\left\{\begin{array}{l}b_{0} \\ b_{1} \\ b_{2} \\ b_{3} \\ b_{4} \\ b_{5} \\ b_{6} \\ b_{7} \\ b_{8} \\ b_{9}\end{array}\right\}=\left\{\begin{array}{c}70 \\ 449 \\ 139 \\ 62.1 \\ 327 \\ 408 \\ 107 \\ 86.4 \\ 95.4 \\ 556\end{array}\right\}$




\subsection{Results and Discussion}

The matrix shown above was solved by using excel program to determine regression parameters. The parameters are as follow:

$b_{o}=5.445, b_{1}=0.4148, b_{2}=0.1571, b_{3}=2.0377, b_{4}=-0.0117, b_{5}=-0.3814, b_{6}=-0.7673, b_{7}=0.7188$, $b_{8}=0.8722, b_{9}=88.41448$

Substituting these parameters into Equation 1 above gives:

$$
\begin{gathered}
Y=5.445+0.4148 x_{1}+0.1571 x_{2}+2.0377 x_{3}-0.0117 x_{4}-0.3814 x_{5}-0.7673 x_{6} \\
+0.7188 x_{7}+0.8722 x_{8}+88.4144 x_{9}-0.186828
\end{gathered}
$$

Equation 12 is the model to determine mud weight. The model is used to estimate the mud weight as shown in Table 3.

Table 3: Estimated mud weight actual quantity of materials

\begin{tabular}{|c|c|c|}
\hline Samples & Actual mud weight $\mathrm{X}_{1}(\mathrm{ppg})$ & Estimated mud weight $\mathrm{X}_{2}(\mathrm{ppg})$ \\
\hline 1 & 10 & 10.03032 \\
\hline 2 & 7 & 6.43063 \\
\hline 3 & 5 & 5.232352 \\
\hline 4 & 7 & 6.788532 \\
\hline 5 & 8 & 6.636182 \\
\hline 6 & 9 & 8.730792 \\
\hline 7 & 9 & 9.385392 \\
\hline 8 & 7 & 7.705802 \\
\hline 9 & 8 & 7.380422 \\
\hline
\end{tabular}

\subsection{Testing the validity of the model}

$H_{0} ; b_{0}=b_{1}=b_{2}=b_{k}=0$

$H_{l}$; At least one $b_{i}$ is not equal to zero (Bill and Nicole, 2012)

If at least one $b_{i}$ is not equation to zero, the model is valid.

$$
\bar{\sigma}_{Y_{1}-Y_{2}}=\sqrt{\left(\frac{Y_{1}+Y_{2}}{N_{1}+N_{2}}\right)\left(\frac{N_{1}+N_{2}}{N_{1} \times N_{2}}\right)}
$$

$$
\begin{array}{ll}
\text { where: } & \\
Y_{1} & \text { Sum of squares for actual mud weight } \\
Y_{2} & \text { Sum of squares for estimated mud weight } \\
N_{1} & \text { Sample size for actual mud weight } \\
N_{2} & \text { Sample size for estimated mud weight } \\
\bar{\sigma}_{Y_{1}-Y_{2}} \quad \text { for the data is } \\
\sqrt{\left(\frac{70+68.380422}{9+9-2}\right)\left(\frac{9+9}{9 * 9}\right)}=1.306774 \\
\sqrt{\mathrm{X}_{1}}=7.777 \\
\overline{\mathrm{X}}_{2}=7.5911 \\
t=\frac{\overline{\mathrm{X}}_{1}-\bar{X}_{2}}{\bar{\sigma}_{Y_{1}-Y_{2}}}=0.1428
\end{array}
$$

The degree of freedom is $N_{1}+N_{2}-2=16$

The obtained $t$-ratio was compared with the table t-ratio for degree of freedom using a two-tailed test ( $H_{O}$ is being tested). 
The obtained $t$ - $t$-ratio is 0.0004472 and tabled $t$-ratio $\left(\alpha=00^{\prime} .05\right)$ for 16 degree of freedom is 1.746 . Since obtained $t$-ratio is less than that of the tabled value, $H_{O}$ is rejected.

The conclusion drawn the $t$-test carried out, therefore, is that there is no significant difference between actual mud weight and the estimated one.

To know whether this assumption is met, the unbiased sample variance of actual mud weight and estimated mud weight subjected to an $F$-test.

The $F$-test is given as (Andy 2000):

$F=\frac{S_{1}^{2}}{S_{2}^{2}}$
where:
$S_{1}^{2} \quad$ the greater variance of the two samples
$S_{2}^{2} \quad$ the lesser variance of the two samples

The standard deviations for actual mud weight and estimated mud weight are given as Equation 15 and 16 respectively.

$S_{1}=\sqrt{\frac{\sum\left(X_{1}-\bar{X}_{1}\right)^{2}}{N_{1}}}$
$S_{2}=\sqrt{\frac{\sum\left(X_{2}-\bar{X}_{2}\right)^{2}}{N_{2}}}$

where:

$X_{1} \quad$ actual mud weight

$X_{2} \quad$ estimated mud weight

$\bar{X}_{1} \quad$ mean of actual mud weight

$\bar{X}_{2} \quad$ estimated mud weight

From Table 3,

$\overline{\mathrm{X}}_{1}=7.777$

$\overline{\mathrm{X}}_{2}=7.5911$

From Equation 15 and 16,

$S_{1}^{2}=2.110232$

$S_{2}^{2}=1.950618$

Therefore, from Equation 14,

$F=\frac{2.110232}{1.950618}=1.081827$

Degree of freedom for greater variance of the mud weight $=9-1=8$

Degree of freedom for lesser variance of the mud weight $=9-1=8$

Checking the significance of the obtained $F$-ratio of 1.081827 with the critical $F$-ratios in the $F$-table, we find that the obtained $F$-ratio is less than the critical $F$ - ratios at both $\alpha=0.05(\mathrm{~F}=3.44)$ and $\alpha=$ $0.01(\mathrm{~F}=6.03)$. The homogeneity of both variances is thus confirmed.

Figure 2 through to Figure 9 it has been shown linearity of the model, it shows that the model is reliable. And control of the production of mud weight is now very easy. If the different quantity of materials is used, the estimated mud weights are shown in Table 4. 
Table 4: Estimation of mud weight using different of materials (chemicals)

\begin{tabular}{|l|l|l|l|l|l|l|l|l|l|l|}
\hline Samples & $\begin{array}{l}\text { Water } \\
(\text { litre }) \\
\mathrm{X}_{1}\end{array}$ & $\begin{array}{l}\text { Caustic } \\
\text { soda } \\
(\mathrm{g})\left(\mathrm{X}_{2}\right)\end{array}$ & $\begin{array}{l}\text { Soda } \\
\text { ash } \\
(\mathrm{g}) \mathrm{X}_{3}\end{array}$ & $\begin{array}{l}\text { Potassium } \\
\text { chloride } \\
(\mathrm{KCl})(\mathrm{g}) \\
\left(\mathrm{X}_{4}\right)\end{array}$ & $\begin{array}{l}\text { Calcium } \\
\text { carbonate } \\
\left(\mathrm{CaCO}_{3}\right) \\
(\mathrm{g}) \mathrm{X}_{5}\end{array}$ & $\begin{array}{l}\mathrm{XCD} \\
\text { Kelzan } \\
(\mathrm{g}) \mathrm{X}_{6}\end{array}$ & $\begin{array}{l}\text { CMC } \\
\text { Hivis } \\
\mathrm{X}_{7}\end{array}$ & $\begin{array}{l}\text { PAC-R } \\
(\mathrm{g}) \\
\mathrm{X}_{8}\end{array}$ & $\begin{array}{l}\text { Barite } \\
(\mathrm{g}) \\
\mathrm{X}_{9}\end{array}$ & $\begin{array}{l}\text { Estimated } \\
\text { mud weight } \\
(\mathrm{ppg}) \mathrm{Y}\end{array}$ \\
\hline 1 & 4 & 2 & 2.5 & 4 & 10 & 3 & 5 & 10 & 8 & 17.635 \\
\hline 2 & 0.01 & 0.01 & 0.02 & 10 & 15 & 3 & 4 & 10 & 6 & 8.1289 \\
\hline 3 & 1 & 0.11 & 0.4 & 6 & 10 & 5 & 4 & 7 & 20 & 5.6552 \\
\hline 4 & 0.004 & 2 & 0.6 & 6 & 0.6 & 3 & 2 & 5 & 26 & 7.2513 \\
\hline
\end{tabular}

Water is the most significant material involved in drilling fluid technology. It is usually readily available at relatively low cost. Among the unusual properties of water in contrast with other liquids are the highest surface tension, dielectric constant, heat of fusion, the heat of vaporization, and the superior ability of water to dissolve different substances. As the quantity of water is increased, the mud weight increases (Brini et al., 2017). The effect of water is in Figure 10.

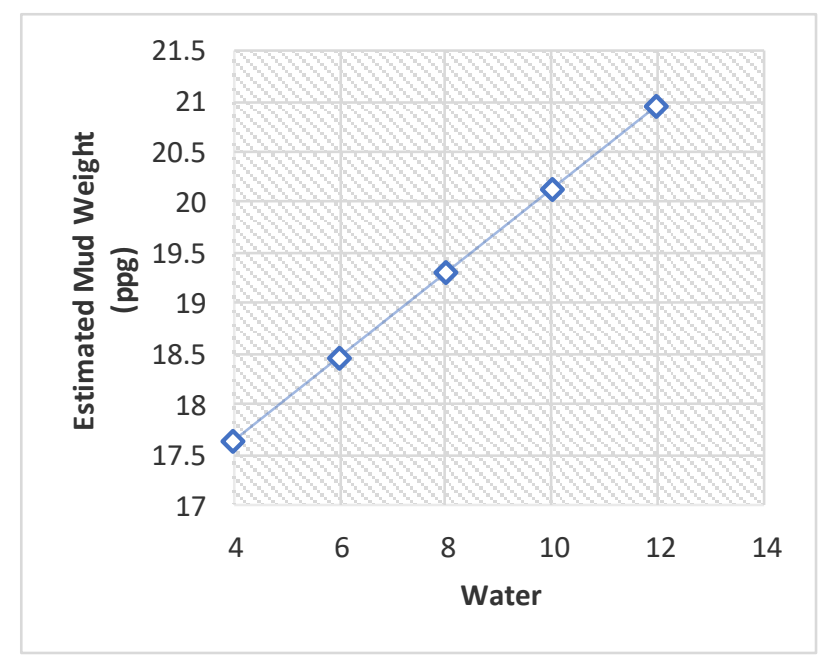

Figure 10: Effect of water used on mud weight

The most important part of these samples is the concentration of $\mathrm{CaCO}_{3}$ as a weighting agent. It is used to increase the densities of samples from 9.0 to 11 pounds per gallon (ppg). The density of mud is the main parameter to consider during the study as it directly affects the formation of a filter cake. The most common additive to increase the mud weight in production (Raheem et al., 2019) as shown in Figure 11.

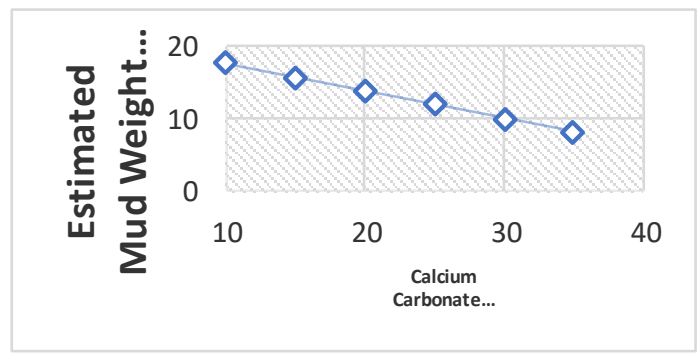

Figure 11: Effect of calcium carbonate $\left(\mathrm{CaCO}_{3}\right)(\mathrm{g})$ used on mud weight

Barite one of the vital roles of drilling mud is the control of formation fluid pressure to avoid blowouts. The density of the mud must be elevated at times to stabilize fragile formations (Ibrahim and Sami, 2017). The effect of Barite is illustrated in Figure 12. 


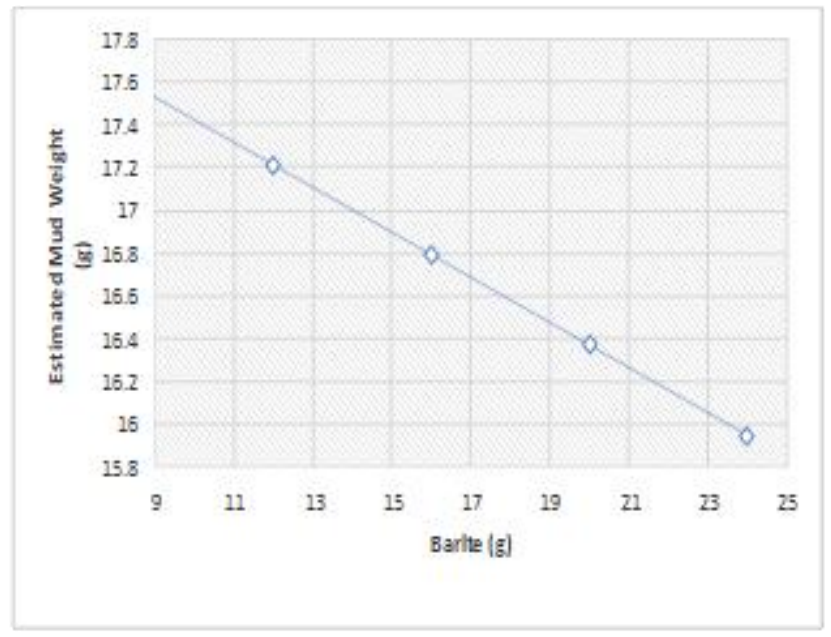

Figure 12: Effect of Barite used on mud weight

Caustic soda is used in water-based mud to increase its $\mathrm{pH}$, to offset corrosion and to counteract hydrogen sulphide. Also, some achievement can be attained by addition of caustic soda to the freshwater sideways with the bentonite to perform as a dispersing agent. Soda ash the principal use of soda ash or sodium carbonate $\left(\mathrm{Na}_{2} \mathrm{CO}_{3}\right)$ is for the exclusion of soluble salts from the makeup of waters and muds and to recover the yield of clay (Annis and Smith, 2012) as shown in Figure 13.

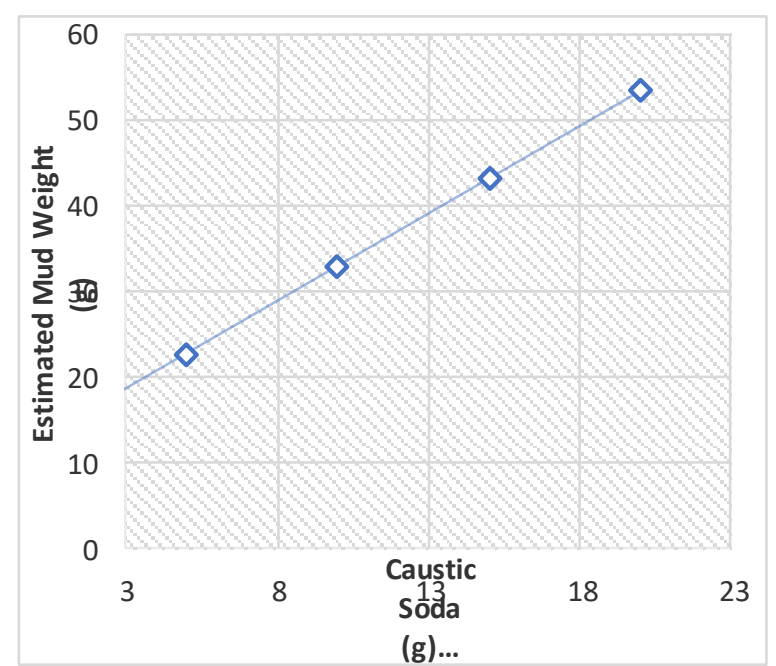

Figure 13: Effect of caustic soda used on mud weight

The experimental data show that rheological properties of a water base mud (plastic viscosity and yield point) are altered when shale formation is encountered when $\mathrm{KCl}$ is use as shown in Figure 14.

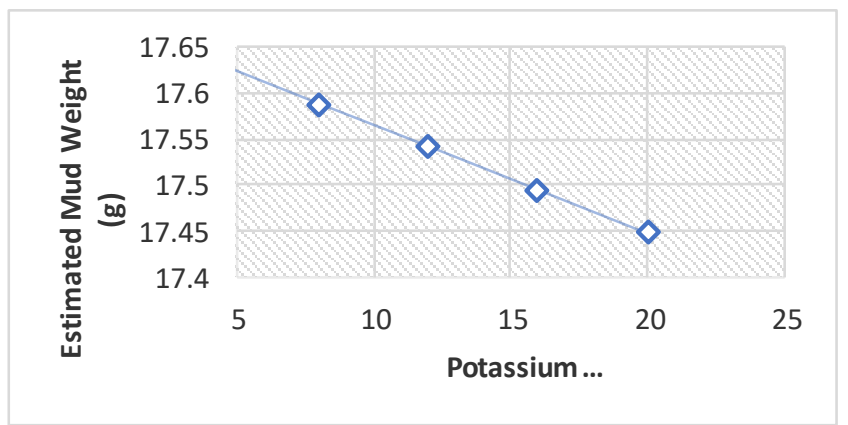

Figure 14: Effect of potassium chloride $(\mathrm{KCl})(\mathrm{g})$ used on mud weight 
The principal use of soda ash or sodium carbonate $\left(\mathrm{Na}_{2} \mathrm{CO}_{3}\right)$ is for the removal of soluble salts from the makeup of waters and muds and to enhance the yield of clay. The effect of Soda ash is shown in Figure 15.

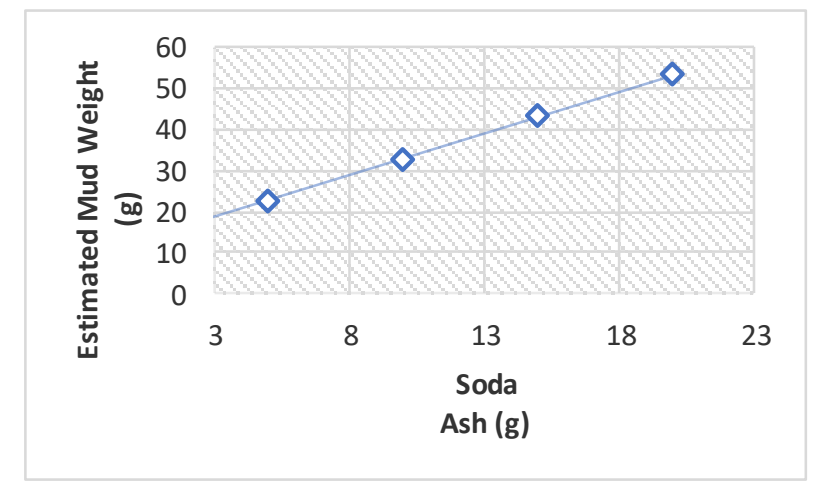

Figure 15: Effect of soda ash (g)used on mud weight

\subsection{Conclusions}

In this study, a model was developed using data obtained from production records. The data include mud weight, water and other Chemicals (Materials) for nine different samples. The data were analysed to establish linearity and the data was substituted into the multiple regression to form a matrix with nine unknown regression parameters which was substituted into the regression equation to form the model. T-test and F -test was used to validate the model. Results from the test suggest that the developed model was reliable. The model was used to estimate mud weight for four samples and the results are reliable. The effect of each variable was also considered and results also show that each of the variables affects the mud weight.

\section{References}

Andy, I. J. (2000). Fundamental for Education and the Behavioral Science's, pp.183-187.

Annis, M. R. and Smith. Drilling Fluids Technology, Published on Sep 10, (2012) 3.1

API Recommended Practice 13B-1, I. 1.-1 Recommended Practice for Field Testing waterbased Drilling Fluids. American Petroleum Institute, (2003).

Bill and Nicole. Multiple Regression, burkewiz@stanford.edu,(2012).

Brini, E., Christopher, I., Fennell, M., Fernandez-Serra, B., Hribar-Lee, M., Luksic and A. D. Ken, (2017). How Water's Properties Are Encoded in Its Molecular Structure and Energies, Chem. Rev. 117(19), pp. 12385-12414. https://doi.org/10.1021/acs.chemrev.7b00259

Burgoyne, A. T., Chenevert, M. E., Mulheim, K. K. and Young, F. S. (1986) Applied Drilling Engineering's Textbook Series, 2(53), pp. 76-77

Enamul, M., Hossain and Mohammed Wajheeuddin, (2016). The use of grass as an environmentally friendly additive in water-based drilling fluids. Petroleum Science, 13, pp. 292-303.

Fadairo, A., Ameloko, A., Adeyemi,G., Ogidigbo, E. and Airend, O. (2012). Environmental Impact Evaluation of a Safe Drilling Mud. SPE, (2012)

Ibrahim, D. S. and Sami, N. A. (2017). Balasubramanian. Effect of barite and gas oil drilling fluid additives on the reservoir rock characteristics. Journal of Petroleum Exploration and Production Technology, 7(1), pp. 281-292. DOI: 10.1007/s13202-016- 0258-2 
John, I. L and Ogbonna, J. (2018) Effect of Weighing Agent on Rheological Properties of Drilling Fluid. IJERT, 7(4), IJERTV7IS040322

Multiple Regression, https://www.utdallas.edu/ scniu/OPRE- 6301/documents/Chapter18. (2019).16.,24.

Øyvind, B. (2017) Drilling fluid properties and design Posted 12.01.

Paulauskiene, T. (2017). Petroleum Extraction Engineering, Intech Open, 2017.DOI: 10.5772/intechopen.70360.

Raheem, I., Zubair, M., Pirzada, F. Abro, A. Muhammad, V. Avinashi (2019). An Experimental Study on the Performance of Calcium Carbonate Extracted from Eggshells as Weighting Agent in Drilling Fluid. Engineering, Technology and Applied Science Research, 9(1), pp. 3859

Sharif, M. D. A., Nagalakshmi, N. V. R. S., Srigowri, R., Vasanth, R. G. and Uma Sankar, K. (2017) Drilling Waste Management and Control the Effects. J Adv Chem Eng, 7(1), DOI: 10.4172/2090- 4568.1000166.

Sir Dele, O. and Joseph, O. (2014). Building Pad Mud (Arkleen Oil and Gas Manual). 